\title{
Detection and surveillance of viral hemorrhagic septicemia virus using real-time RT-PCR. I. Initial comparison of four protocols
}

\author{
Janet V. Warg ${ }^{1, *}$, Travis Clement ${ }^{2}$, Emily R. Cornwell ${ }^{3}$, Angela Cruz ${ }^{1}$, \\ Rodman G. Getchell ${ }^{3}$, Cem Giray ${ }^{4}$, Andrew E. Goodwin ${ }^{5}$, Geoffrey H. Groocock ${ }^{3}$, \\ Mohamed Faisal ${ }^{6}$, Robert Kim ${ }^{6}$, Gwenn E. Merry ${ }^{5}$, Nicholas B. D. Phelps ${ }^{7}$, \\ Monica M. Reising ${ }^{8}$, Isaac Standish ${ }^{6}$, Yan Zhang ${ }^{9}$, Kathy Toohey-Kurth ${ }^{10}$ \\ ${ }^{1}$ Diagnostic Virology Laboratory, National Veterinary Services Laboratories, VS, APHIS, USDA, Ames, Iowa 50010, USA \\ ${ }^{2}$ Veterinary and Biomedical Sciences Department, Animal Disease Research and Diagnostic Laboratory, \\ South Dakota State University, Brookings, South Dakota 57007, USA \\ ${ }^{3}$ Aquatic Animal Health Program, Department of Microbiology and Immunology, Cornell University, Ithaca \\ New York 14853, USA \\ ${ }^{4}$ Kennebec River Biosciences, Richmond, Maine 04357, USA \\ ${ }^{5}$ Aquaculture/Fisheries Center, University of Arkansas Pine Bluff, Pine Bluff, Arkansas 71601, USA \\ ${ }^{6}$ Aquatic Animal Health Laboratory, College of Veterinary Medicine, Michigan State University, East Lansing, \\ Michigan 48824, USA \\ ${ }^{7}$ Veterinary Diagnostic Laboratory, University of Minnesota, St. Paul, Minnesota 55108, USA \\ ${ }^{8}$ Center for Veterinary Biologics, VS, APHIS, USDA, Ames, Iowa 50010, USA \\ ${ }^{9}$ Animal Disease Diagnostic Laboratory, Ohio Department of Agriculture, Reynoldsburg, Ohio 43068, USA \\ ${ }^{10}$ Wisconsin Veterinary Diagnostic Laboratory, University of Wisconsin, Madison, Wisconsin 53706, USA
}

\begin{abstract}
Eight laboratories worked collectively to evaluate 4 real-time RT-PCR (rRT-PCR) protocols targeting viral hemorrhagic septicemia virus (VHSV) being considered for deployment to a USA laboratory testing network. The protocols utilized previously published primers and probe sets developed for detection and surveillance of VHSV. All participating laboratories received and followed a standard operating protocol for extraction and for each of the rRT-PCR assays. Performance measures specifically evaluated included limit of detection (defined as the smallest amount of analyte in which $95 \%$ of the samples are classified as positive), analytical specificity, assay efficiency across genotype representatives, within- and between-plate variation within a laboratory, and variation between laboratories using the same platform, between platforms, and between software versions. This evaluation clearly demonstrated that the TaqMan ${ }^{\circledR}$-based assay developed by Jonstrup et al. (2013; J Fish Dis 36:9-23) produced the most consistent analytical performance characteristics for detecting all genotypes of VHSV across the 8 participating laboratories.
\end{abstract}

KEY WORDS: VHSV - Surveillance - Real-time RT-PCR · Analytical sensitivity · Analytical specificity $\cdot$ Validation

Resale or republication not permitted without written consent of the publisher

\section{INTRODUCTION}

Viral hemorrhagic septicemia virus (VHSV) is the causative agent of a highly contagious disease of both saltwater and freshwater fish in the northern hemi- sphere. VHSV is a novirhabdovirus (Rhabdoviridae) (Tordo et al. 2005) that is listed as a notifiable pathogen by the World Organization for Animal Health (OIE). The severity of infection and its outcome varies by fish species, age, immune status, and prevailing 
environmental conditions. Dependent on the species of fish, infection may result in substantial mortality (Smail \& Snow 2011, Kim \& Faisal 2010a,b,c, Groocock et al. 2012). VHSV can become endemic in fish populations, with some individual fish serving as carriers of the virus and periodically shedding the virus, which causes repeat episodes of disease in naïve fish populations (Hershberger et al. 2010, Kim \& Faisal 2012). Since its emergence in the Laurentian Great Lakes of North America, the novel sublineage of VHSV genotype IV has caused several large-scale die-offs of wild fish and spread into the 5 Great Lakes, a number of inland lakes, and several streams (Elsayed et al. 2006, Gagné et al. 2007, Groocock et al. 2007, Lumsden et al. 2007, Cornwell et al. 2011, 2012). VHSV is now endemic in the Great Lakes and represents a serious risk to farmed fish populations within the Great Lakes watershed as well as a risk for dissemination of the virus to other watersheds within or outside the USA by movement of fish (reviewed by Faisal et al. 2012).

The current gold standard for detection of VHSV in either clinical or non-clinical fish is virus isolation in cell culture followed by virus identification (AFS-FHS 2010, OIE 2012). Virus isolation in cell culture is a long and labor-intensive process. Multiple real-time RTPCR (rRT-PCR) assays with rapid turnaround time have been developed and suggested for use in VHSV surveillance efforts or for routine diagnosis of viral hemorrhagic septicemia (VHS) (Chico et al. 2006, Liu et al. 2008, Matejusova et al. 2008, 2010, Cutrín et al. 2009, Hope et al. 2010, Garver et al. 2011, Jonstrup et al. 2013, Pierce et al. 2013a,b). However, in order to consider utilization of any VHSV rRT-PCR assay in surveillance or diagnostic activities where testing is conducted in multiple laboratories and where the results from multiple laboratories may be used to support declarations of freedom from the pathogen, the testing protocol must be standardized, robust, and performance estimates well characterized.

The definition of what constitutes a standardized testing protocol varies. For rRT-PCR assays, the OIE Aquatic Diagnostic Manual frequently lists primers, probe, and cycling conditions but lacks many of the details that can influence a test's outcome. Quality controls (such as extraction and amplification controls and acceptable cycle threshold [Ct] value ranges for positive extraction and amplification controls) and interpretation criteria need to be defined in the standardized testing protocol. To this end, the USDAAPHIS coordinated efforts of 8 laboratories to compare the analytical performance of 4 rRT-PCR protocols that utilized 3 previously published primers and probe sets (Hope et al. 2010, Garver et al. 2011, Phelps et al. 2012, Jonstrup et al. 2013) following OIE validation guidelines. In addition, the purpose of this comparison is exclusively for detection (an unequivocal positive or negative test result) of VHSV for diagnosis or surveillance, although the assays could be used for relative quantitation purposes. The participating laboratories received and followed a standard operating protocol for extraction and for each of the rRT-PCR assays. This paper reports the criteria used for the comparison of assay performance across participating laboratories as well as the results. Performance measures specifically investigated included limit of detection (LOD), defined as the smallest amount of analyte in which $95 \%$ of the samples are classified as positive, analytical specificity, estimates of assay efficiency across genotype representatives, within- and between-plate variation within a laboratory, variation between laboratories using the same platform, between platforms, and between software versions. In addition, both the LOD and the efficiency estimates can be used as indicators of laboratory/technician sensitivity differences related to sample handling (serial dilutions of virus stocks) within a testing laboratory. Performance measures were used collectively to select assays for further evaluation and to make recommendations on the suitability of each of these assays for surveillance and diagnostic purposes.

\section{MATERIALS AND METHODS}

\section{Samples and standards}

Virus strains representing the 4 different VHSV genotypes were used in this study (Table 1); these included reference viruses and field isolates. Tissue culture infectious dose $50 \%\left(\mathrm{TCID}_{50}\right)$ per $\mathrm{ml}$ titers were calculated for each VHSV stock by the Spearman-Kärber method as modified by Finney (1978) in a 96-well plate format using 10-fold serial dilutions. Fish tissue and fish pathogens (see Table 3) were used to evaluate analytical specificity (exclusivity). Positive amplification controls (PAC) included 2 different sets (3 concentrations in each set) of VHSVrelevant RNA standards. A VHSV-infected round goby RNA standard set (Hope et al. 2010) was used during Phase I testing, and a VHSV MI03 isolate RNA standard set was used during Phase II testing. Each laboratory used its own VHSV reference virus as a positive extraction control. Negative extraction controls were diluents (cell culture medium) utilized at each participating laboratory. Negative amplification control was RNA elution buffer or water. 


\section{RNA extraction}

The MagMAX ${ }^{\mathrm{TM}}$-96 Viral RNA Isolation Kit (Ambion ${ }^{\circledR}$ kit 1836, Life Technologies) was used to extract nucleic acids using either an automated or manual system (Shah et al. 2009). Automated systems included MagMAX ${ }^{\mathrm{TM}}$ Express (Applied Biosystems (ABI), Life Technologies), or Kingfisher (Thermo Fisher Scientific), or BioSprint 96 (Qiagen) magnetic particle processors; and manual systems used an Ambion magnetic plate stand following the manufacturer's instructions. Protocol AM1836 DW 50 v2 Aqua (ABI, Life Technologies) was followed for the automated extraction.

\section{rRT-PCR}

Three previously published VHSV-specific primer and probe sets (identified as the Garver, Hope, and Jonstrup assays in this study) were selected based on

Table 1. Viral hemorrhagic septicemia virus (VHSV) reference isolates used for establishing limit of detection and amplification efficiency

\begin{tabular}{|c|c|c|c|c|c|}
\hline \multirow{4}{*}{$\begin{array}{l}\text { Year was } \\
\text { corrected } \\
\text { after } \\
\text { publication }\end{array}$} & \multirow{2}{*}{$\begin{array}{l}\text { F13.02.97 } \\
\text { Makah }\end{array}$} & \multirow{2}{*}{$\begin{array}{l}\text { III } \\
\text { IVa }\end{array}$} & \multirow{2}{*}{$\begin{array}{l}\text { Farmed; Ireland } \\
\text { Hatchery; USA }\end{array}$} & Turbot & \multirow{2}{*}{$\begin{array}{l}1997 \\
1988\end{array}$} \\
\hline & & & & Coho salmon & \\
\hline & ME03 & IVa & Atlantic Ocean & Herring & 2003 \\
\hline & $2000-149$ & IVC & Ruisseau George-Collette, & Mummichog & 2000 \\
\hline & MI03 & $\mathrm{IVb}$ & Lake St. Clair, USA & Muskellunge & 2003 \\
\hline & 2004-175 & IVc & French River, Canada & Brown trout & 2004 \\
\hline & FPL2006-005 & $\mathrm{IVb}$ & St. Lawrence River, USA & Round goby & 2006 \\
\hline
\end{tabular}

published performance characteristics, scientific validity data including performance in species and population to be tested, and international acceptance (Hope et al. 2010, Garver et al. 2011, Jonstrup et al. 2013). The Hope and the Jonstrup assays are singletube assays where both reverse transcription (RT) and PCR occur in a single tube using primers specific for a fragment of the nucleoprotein $(\mathrm{N})$ gene of VHSV. The Garver assay is a 2-step assay that requires RT of RNA to cDNA using random primers in 1 tube, followed by real-time PCR in a second tube. A fourth assay (identified as the Phelps assay in this study) utilized the Garver primers and probe in a single tube format (Phelps et al. 2012).

The purpose of Phase I was to establish performance characteristics on a single platform and software package to be used as the 'reference standard platform.' Criteria for selection of laboratories for this phase were those conducting VHSV surveillance, movement, or confirmation testing on fish collected from the Great Lakes watershed and had the reference platform and software in the laboratory (Table 2). Three laboratories (A, B, and C) tested 9 VHSV isolates, representing the 4 genotypes, with the 4 different rRT-PCR methods on the ABI 7500 - software version 1.4 platform (ABI, Life Technologies). From a single stock for each isolate, each laboratory created 3 separate 10 -fold serial dilutions spanning concentrations $10^{-1}$ through $10^{-8}$. Total RNA

Table 2. Laboratory information. PCR experience levels were categorized as High: extensive experience with high-throughput rRT-PCR testing for multiple pathogens; Some: recent experience with high-throughput VHSV rRT-PCR testing; Recently trained: experience with high sample testing numbers but recently trained to perform rRT-PCR

\begin{tabular}{|c|c|c|c|c|c|}
\hline Lab & Platform & Manufacturer & $\begin{array}{l}\text { Software } \\
\text { version }\end{array}$ & Function & $\begin{array}{l}\text { rRT-PCR } \\
\text { experience }\end{array}$ \\
\hline A & ABI 7500 & ABI, Life Technologies & 1.4 & Diagnostic & High \\
\hline B & ABI 7500 & ABI, Life Technologies & 1.4 & Diagnostic & Recently trained \\
\hline $\mathrm{C}$ & ABI 7500 & ABI, Life Technologies & 1.4 & Research and diagnostic & Some \\
\hline $\mathrm{D}$ & ABI 7500 & ABI, Life Technologies & 1.4 & Diagnostic & High \\
\hline $\mathrm{E}$ & Mastercycle ${ }^{\circledR}$ EP Realplex & Eppendorf & 1.5 & Diagnostic & High \\
\hline $\mathrm{F}$ & Mastercycle ${ }^{\circledR}$ EP Realplex & Eppendorf & 2.2 & Research and diagnostic & Recently trained \\
\hline $\mathrm{G}$ & BioRad iCycler iQ ${ }^{\mathrm{TM}}$ & BioRad & 3.1 & Research and diagnostic & Recently trained \\
\hline $\mathrm{H}$ & ABI 7500 & ABI, Life Technologies & 2.0 & Diagnostic & Recently trained \\
\hline
\end{tabular}


was extracted from $50 \mu$ of each replicate 10 -fold serial dilution. Individual RNA samples were analyzed once by each assay, and $\mathrm{Ct}$ values were recorded for use in determining test performance characteristics. Controls for every run included negative extraction controls, negative amplification controls, positive extraction controls, and positive amplification controls. Estimates for LOD were considered in conjunction with the estimates for efficiency when comparing assays.

The purpose of Phase II was to establish performance characteristics in laboratories (hereafter 'Labs') that utilized alternative platforms and software. Criteria for selection of labs for this phase were those conducting VHSV surveillance or movement testing on fish collected from outside the Great Lakes watershed and/or had a different platform and software in the lab. Five labs (D, E, F, G, and H) tested 4 VHSV genotype IV isolates using 2 different rRTPCR methods (Jonstrup and Phelps methods) as outlined in Phase I. Platforms and software used for this phase are listed in Table 2. Phase II data allowed for a comparison of platforms or an individual lab's performance with the reference standard platform. Comparison of Labs A, B, C, and D was a direct comparison of labs or individuals performing the assay in a lab as the platform is the same in each of these labs and a single individual performed the test in each lab (lab and technical operator are confounded). The ABI 7500 (software version 1.4) platform used by Labs A, B, and C in Phase I testing was considered the 'reference standard platform'; Lab D also used the reference standard platform during Phase II testing. Phase II results from Labs D, $\mathrm{E}, \mathrm{F}, \mathrm{G}$, and $\mathrm{H}$ (other platforms or individuals) were compared to Phase I results from Labs A, B, and C. Lab $F$ had 2 individuals $\left(F_{1}\right.$ and $\left.F_{2}\right)$ perform the testing.

\section{Determination of assay performance characteristics}

\section{Data interpretation}

The Ct value of a rRT-PCR reaction is defined by the threshold line set within the exponential phase of the logarithmic scale amplification plot, and the baseline reflects the background or noise in the reactions. For the reference standard platform (ABI 7500, software version 1.4), the auto $\mathrm{Ct}$ algorithm, which calculates baseline and threshold parameters based on the assumption that data sets will exhibit charac- teristic amplification curves, was utilized. After each analysis, the baseline and threshold parameters were reviewed. When the baseline was set too low (higher background on a run), a second analysis was performed using auto threshold and manual baseline settings ( 3 to 15 cycles). The Auto $\mathrm{Ct}$ algorithm was used for the BioRad iCycler $\mathrm{iQ}^{\mathrm{TM}}$ software version 3.1. For the Mastercycler ${ }^{\circledR}$ EP Realplex software version 1.5 the best-fit algorithm was used to set the baseline and threshold. Threshold setting for the Mastercycler ${ }^{\circledR}$ EP Realplex software version 2.2 was problematic, as neither the best fit nor noiseband algorithm (software defined) produced repeatable results. Thresholds were manually established for the Mastercycle ${ }^{\circledR}$ EP Realplex software version 2.2 based on a set percentage of the plateau of the low positive amplification control (ABI recommendation to optimize consistency across platforms and for correct data interpretation for low copy number samples).

\section{Analytical sensitivity}

The LOD was determined as the concentration (TCID $_{50}$ per ml titer) corresponding to the last serial dilution in which all 3 replicates tested positive. A regression analysis was conducted $(\mathrm{Ct}$ versus $-\log _{10}$ dilution) on the data from each laboratory for each isolate by rRT-PCR method using only the data within the LOD. The slope of the regression line was used to estimate the amplification efficiency $(\mathrm{AE})$ and was reported as a percentage: $\mathrm{AE}=100 \times$ $\left(10^{1 / \text { slope }}-1\right)$. Comparison of each laboratory's performance characteristics (LOD and AE) by isolate and method were performed.

Repeatability and reproducibility

Linear mixed effects models were fit to $\mathrm{Ct}$ values obtained for the VHSV MI03 RNA standard set (provided to laboratories) produced by each assay for each laboratory. The models included a fixed dilution effect, a random plate effect, a random dilution by plate effect, and a random error. The square root of the variance of the random error was reported as the within-plate variability. The square root of the sum of the variances of the random plate and random dilution by plate effects was reported as the betweenplate variability. The total variability was reported as the square root of the sum of all variance components (Vardeman \& Jobe 1999). 


\section{Analytical specificity}

Labs D, E, F, and G conducted specificity testing. Reference cultures or field isolates (Table 3) were diluted to obtain a high concentration (approximately 10000 genome copies) and a low concentration (approximately 100 genome copies) for nucleic acid extraction. Each nucleic acid sample was tested in duplicate by both the Jonstrup and the Phelps assays.

Table 3. Diagnostic matrices used to demonstrate analytical specificity

\begin{tabular}{|c|c|c|}
\hline Strain or species & Common name & $\begin{array}{l}\text { Testing } \\
\text { lab(s) }\end{array}$ \\
\hline \multicolumn{3}{|l|}{ Virus } \\
\hline Aquareovirus $A$ & Chum salmon reovirus & G \\
\hline Aquareovirus B & $\begin{array}{l}\text { Green river chinook } \\
\text { reovirus }\end{array}$ & G \\
\hline Aquareovirus $B$ & Eel lake reovirus & $\mathrm{G}$ \\
\hline Aquareovirus $C$ & Golden shiner virus & $\mathrm{G}$ \\
\hline Aquareovirus $D$ & $\begin{array}{l}\text { American grass } \\
\text { carp reovirus }\end{array}$ & $\mathrm{G}$ \\
\hline Cyprinid herpesvirus 3 & Koi herpesvirus & $\mathrm{E}$ \\
\hline Fathead minnow nidovirus & & $\mathrm{G}$ \\
\hline Ictalurid herpesvirus 1 & Channel catfish virus & G \\
\hline $\begin{array}{l}\text { Infectious hematopoietic } \\
\text { necrosis virus }\end{array}$ & & $\mathrm{D}, \mathrm{E}$ \\
\hline $\begin{array}{l}\text { Infectious pancreatic } \\
\text { necrosis virus }\end{array}$ & & $\mathrm{D}, \mathrm{E}, \mathrm{F}$ \\
\hline Largemouth bass virus & & $\mathrm{D}, \mathrm{E}, \mathrm{F}$ \\
\hline Picornavirus & & G \\
\hline Spring viremia carp virus & & $\mathrm{D}$ \\
\hline \multicolumn{3}{|l|}{ Bacteria } \\
\hline Aeromonas hydrophila & & $\mathrm{E}, \mathrm{F}$ \\
\hline Aeromonas salmonicida & & $\mathrm{D}, \mathrm{F}$ \\
\hline Flavobacterium psychrophilum & & $\mathrm{D}, \mathrm{F}$ \\
\hline Flavobacterium columnare & & F \\
\hline Pseudomonas aeruginosa & & $\mathrm{D}, \mathrm{E}$ \\
\hline Reinbacterium salmoninarum & & $\mathrm{F}$ \\
\hline Shewanella putrefaciens & & $E, F$ \\
\hline Streptococcus uberis & & $\mathrm{E}$ \\
\hline Yersinia ruckeri & & $\mathrm{D}, \mathrm{F}$ \\
\hline \multicolumn{3}{|l|}{ Fish } \\
\hline Ameiurus nebulosus & Bullhead & $\mathrm{D}$ \\
\hline Catostomus commersonii & White sucker & $\mathrm{D}$ \\
\hline Cyprinus carpio & Common carp & $\mathrm{D}$ \\
\hline Esox masquinongy $\times$ Esox lucius & Tiger muskellunge hybrid & $\mathrm{D}$ \\
\hline Etheostoma exile & Iowa darter & $\mathrm{D}$ \\
\hline Hybognathus hankinsoni & Brassy minnow & $\mathrm{D}$ \\
\hline Lepomis cyanellus & Green sunfish & $\mathrm{D}$ \\
\hline Lepomis macrochirus & Bluegill & $\mathrm{D}$ \\
\hline Micropterus dolomieu & Smallmouth bass & $\mathrm{D}$ \\
\hline Morone chrysops & White bass & $\mathrm{D}$ \\
\hline Perca flavescens & Yellow perch & $\mathrm{D}$ \\
\hline Pimephales promelas & Fathead minnow & $\mathrm{D}$ \\
\hline Pomoxis nigromaculatus & Black crappie & $\mathrm{D}$ \\
\hline Sander vitreus & Walleye & $\mathrm{D}$ \\
\hline
\end{tabular}

\section{RESULTS}

\section{Phase I}

LOD estimates (Table 4) on isolates representative of VHSV genotypes varied by isolate and assay as expected given the nucleic acid variation between genotypes and different starting concentrations of the isolates. There was not a single laboratory that had the best sensitivity (LOD) across all isolates for an assay or across assays. The Hope assay did not detect the genotype I virus (DK5151). Both the Garver and the Hope assays only detected a high concentration (4-5 logs of virus) of genotype II virus (1p53). Regression analysis (Table 5) of the data for 3 labs (A, B, and C) revealed similar $\mathrm{AE}$ for an assay regardless of an isolate's genotype within a lab when there was a positive detection. Linear regression analysis on the data set for several isolates tested with the Phelps assay in Lab $\mathrm{C}$ did not hold a constant linear relationship between $\mathrm{Ct}$ value and dilution across all concentrations tested (Fig. 1). The Jonstrup assay consistently detected low concentrations of all genotypes and had high efficiency estimates (87-97; 92-98; 97-109) in all 3 labs. Plots of the regression analysis (data not shown) as it relates to the cut-off values utilized in all assays suggest that cutoff values exceeded the linear relationship between the $\mathrm{Ct}$ value and $-\log _{10}$ dilution of the virus stock. The Jonstrup and the Phelps assays were chosen for Phase II testing, as both assays detected all genotypes of VHSV known to date. The Phelps assay was chosen over the Garver assay, as 1-step assays are technically more convenient to perform and have higher throughput capacity and did a better job at detecting genotype representatives used in this study.

\section{Phase II}

Analytical sensitivity

Five labs (D, E, F, G, and H) determined LOD for genotype IV isolates only. A regression analysis to obtain amplifica- 
Table 4. Limit of detection estimates are defined as the concentration corresponding to the last serial dilution in which all 3 replicates tested positive. Titer is tissue culture infective dose $\left(\mathrm{TCID}_{50}\right) \mathrm{ml}^{-1}$; ND: not detected; $(-)$ virus not tested

\begin{tabular}{|c|c|c|c|c|c|c|c|c|c|}
\hline \multirow{2}{*}{$\begin{array}{l}\text { Method } \\
\text { Lab }\end{array}$} & \multirow[b]{2}{*}{$\begin{array}{l}\text { DK5151 } \\
\text { (Ia) }\end{array}$} & \multirow[b]{2}{*}{$\begin{array}{l}\text { 1p53 } \\
\text { (II) }\end{array}$} & \multirow[b]{2}{*}{$\begin{array}{c}\text { F13.02.97 } \\
\text { (III) }\end{array}$} & \multirow{2}{*}{$\begin{array}{c}\text { Makah } \\
\text { (IVa) }\end{array}$} & \multirow{2}{*}{$\begin{array}{c}\text { late ID } \\
\text { ME03 } \\
\text { (IVa) }\end{array}$} & \multirow{2}{*}{$\begin{array}{l}\text { enotype) } \\
2000-149 \\
\text { (IVc) }\end{array}$} & \multirow[b]{2}{*}{$\begin{array}{l}\text { MI03 } \\
\text { (IVb) }\end{array}$} & \multirow[b]{2}{*}{$\begin{array}{c}2004-175 \\
\text { (IVb) }\end{array}$} & \multirow[b]{2}{*}{$\begin{array}{l}\text { FPL2006-005 } \\
\text { (IVb) }\end{array}$} \\
\hline & & & & & & & & & \\
\hline Titer & 8.4 & 7.1 & 8.2 & 7.1 & 7.3 & 8.3 & 8.1 & 6.1 & 8.4 \\
\hline \multicolumn{10}{|c|}{ Hope et al. (2010) } \\
\hline A & ND & 5.1 & 2.2 & 2.1 & 1.3 & 3.3 & 3.1 & 1.1 & 3.4 \\
\hline B & ND & 5.1 & 2.2 & 2.1 & 1.3 & 2.3 & 2.1 & 0.1 & 1.4 \\
\hline $\mathrm{C}$ & ND & 4.1 & 2.2 & 2.1 & 1.3 & 2.3 & 2.1 & 0.1 & 1.4 \\
\hline \multicolumn{10}{|c|}{ Garver et al. (2011) } \\
\hline A & 3.4 & 6.1 & 3.2 & 3.1 & 2.3 & 3.3 & 3.1 & 1.1 & 2.4 \\
\hline B & 2.4 & ND & 4.2 & 3.1 & 2.3 & 3.3 & 2.1 & 1.1 & 3.4 \\
\hline $\mathrm{C}$ & 3.4 & 6.1 & 4.2 & 2.1 & 2.3 & 2.3 & 2.1 & 1.1 & 2.4 \\
\hline \multicolumn{10}{|c|}{ Phelps et al. (2012) } \\
\hline A & 2.4 & 3.1 & 3.2 & 2.1 & 1.3 & 2.3 & 2.1 & 0.1 & 2.4 \\
\hline B & 2.4 & 3.1 & 3.2 & 2.1 & 1.3 & 2.3 & 1.1 & 1.1 & 2.4 \\
\hline $\mathrm{C}$ & 2.4 & 3.1 & 3.2 & 3.1 & 2.3 & 3.3 & 3.1 & 2.1 & 2.4 \\
\hline $\mathrm{D}$ & - & - & - & 2.1 & 1.3 & 2.3 & - & - & 2.4 \\
\hline E & - & - & - & 3.1 & 2.3 & 3.3 & - & - & 3.4 \\
\hline $\mathrm{F}$ & - & - & - & 4.1 & 3.3 & 4.3 & - & - & 4.4 \\
\hline $\mathrm{G}$ & - & - & - & 4.1 & 3.3 & 4.3 & - & - & 3.4 \\
\hline $\mathrm{H}$ & - & - & - & 2.1 & 1.3 & 3.3 & - & - & 2.4 \\
\hline \multicolumn{10}{|c|}{ Jonstrup et al. (2013) } \\
\hline A & 2.4 & 1.1 & 2.2 & 2.1 & 2.3 & 2.3 & 2.1 & 1.1 & 3.4 \\
\hline $\mathrm{B}$ & 2.4 & 1.1 & 2.2 & 2.1 & 2.3 & 3.3 & 2.1 & 1.1 & 3.4 \\
\hline $\mathrm{C}$ & 1.4 & 1.1 & 1.2 & 3.1 & 1.3 & 2.3 & 2.1 & 0.1 & 2.4 \\
\hline $\mathrm{D}$ & - & - & - & 2.1 & 1.3 & 2.3 & - & - & 2.4 \\
\hline $\mathrm{E}$ & - & - & - & 2.1 & 1.3 & 2.3 & - & - & 2.4 \\
\hline $\mathrm{F}$ & - & - & - & 4.1 & 3.3 & 3.3 & - & - & 3.4 \\
\hline $\mathrm{G}$ & - & - & - & 3.1 & 1.3 & 2.3 & - & - & 2.4 \\
\hline $\mathrm{H}$ & - & - & - & 3.1 & 1.3 & 3.3 & - & - & 2.4 \\
\hline
\end{tabular}

tion efficiency estimates was conducted on the data from each laboratory for each assay-isolate combination (Table 5). Efficiency estimates based on regression analysis were used to evaluate the performance of each assay in participating laboratories since $\mathrm{Ct}$ values cannot be used when comparing experiments where different platforms and software are used. In these instances, the AE is based on a model with only those concentrations in which it was reasonable to assume a constant linear relationship.

Lab D used the same platform and software as Labs A, B, and C, but did not meet both of the selection criteria for Phase I. Lab H used the same platform as the reference standard platform with the exception of a newer version of the software. Lab E used a different platform/software from the reference standard platform. The LOD estimates (Fig. 2) for both the Jonstrup and the Phelps assays were similar across Labs A to E and H. For the Jonstrup assay, Labs D and E consistently had the best LOD (lowest titer of virus detected).

Lab F had an LOD estimate (Fig. 2) 1 log higher than the largest observed estimate across Labs A to D for 2 of the isolates and was similar to the worst observed estimate across Labs A to D for the other 2 isolates for the Jonstrup assay. The LOD estimates for Lab F across all isolates were 1 log worse than the observed estimates across Labs A to D for the Phelps assay.

Lab G used a different platform/software than any of the other participating labs. For the Jonstrup assay, the LOD estimates (Fig. 2) were similar to observed estimates across labs A to E and H. For 3 of the 4 isolates, LOD estimates were $1 \log$ worse than the largest LOD estimate provided by Labs A, B, C, or D using the Phelps assay.

Efficiency estimates (Table 5) for Labs D to H using the Jonstrup assay were similar to the estimates observed by the reference standard laboratories, but the span was larger across isolates. There was more consistency in the efficiency estimates for Labs A, B, D (with exception of the Makah isolate), and E. Efficiency estimates (Table 5) for Labs $\mathrm{F}$ and $\mathrm{H}$ on the Makah isolate were lower than the estimates observed by the reference laboratories. Efficiency estimates for Lab $\mathrm{H}$ on the ME03 isolate and estimates for Labs F and H on the FPL2006-005 isolate were higher than the estimates observed by the reference labs. 
Table 5. Amplification efficiency (AE) estimates (\%). ND: not detected; $(-)$ virus not tested

\begin{tabular}{|c|c|c|c|c|c|c|c|c|c|}
\hline \multirow{2}{*}{$\begin{array}{l}\text { Method } \\
\text { Lab }\end{array}$} & \multirow[b]{2}{*}{$\begin{array}{c}\text { DK5151 } \\
\text { (Ia) }\end{array}$} & \multirow[b]{2}{*}{$\begin{array}{l}\text { 1p53 } \\
\text { (II) }\end{array}$} & \multirow[b]{2}{*}{$\begin{array}{c}\text { F13.02.97 } \\
\text { (III) }\end{array}$} & \multirow{2}{*}{$\begin{array}{c}\text { Is } \\
\text { Makah } \\
\text { (IVa) }\end{array}$} & \multirow{2}{*}{$\begin{array}{c}\text { late ID } \\
\text { ME03 } \\
\text { (IVa) }\end{array}$} & \multirow{2}{*}{$\begin{array}{c}\text { jenotype) } \\
\text { 2000-149 } \\
\text { (IVc) }\end{array}$} & \multirow[b]{2}{*}{$\begin{array}{l}\text { MI03 } \\
\text { (IVb) }\end{array}$} & \multirow[b]{2}{*}{$\begin{array}{l}2004-175 \\
\text { (IVb) }\end{array}$} & \multirow[b]{2}{*}{$\begin{array}{c}\text { FPL2006-005 } \\
\text { (IVb) }\end{array}$} \\
\hline & & & & & & & & & \\
\hline \multicolumn{10}{|c|}{ Hope et al. (2010) } \\
\hline A & ND & ND & 87 & 80 & 89 & 80 & 81 & 85 & 85 \\
\hline B & ND & ND & 96 & 98 & 96 & 97 & 94 & 95 & 102 \\
\hline $\mathrm{C}$ & ND & ND & 105 & 87 & 103 & 106 & 94 & 97 & 96 \\
\hline \multicolumn{10}{|c|}{ Garver et al. (2011) } \\
\hline $\mathrm{A}$ & 88 & ND & 97 & 91 & 96 & 91 & 94 & 93 & 102 \\
\hline $\mathrm{B}$ & 97 & ND & 105 & 100 & 90 & 93 & 90 & 96 & 97 \\
\hline $\mathrm{C}$ & 119 & ND & 131 & 110 & 113 & 116 & 106 & 104 & 104 \\
\hline \multicolumn{10}{|c|}{ Phelps et al. (2012) } \\
\hline A & 107 & 113 & 108 & 106 & 105 & 115 & 110 & 115 & 112 \\
\hline B & 118 & 125 & 121 & 117 & 110 & 113 & 111 & 117 & 111 \\
\hline $\mathrm{C}$ & 127 & 155 & 144 & $161^{\mathrm{a}}$ & $172^{\mathrm{a}}$ & $179^{\mathrm{a}}$ & $157^{\mathrm{a}}$ & 153 & $172^{\mathrm{a}}$ \\
\hline $\mathrm{D}$ & - & - & - & 124 & 106 & 105 & - & - & 103 \\
\hline $\mathrm{E}$ & - & - & - & 109 & 107 & 111 & - & - & 109 \\
\hline $\mathrm{F}$ & - & - & - & 88 & $102^{\mathrm{a}}$ & 101 & - & - & 92 \\
\hline $\mathrm{G}$ & - & - & - & 86 & 102 & 104 & - & - & 97 \\
\hline $\mathrm{H}$ & - & - & - & 118 & 121 & 111 & - & - & 117 \\
\hline \multicolumn{10}{|c|}{ Jonstrup et al. (2013) } \\
\hline A & 95 & 91 & 90 & 89 & 94 & 94 & 97 & 93 & 96 \\
\hline B & 95 & 95 & 95 & 93 & 98 & 93 & 92 & 93 & 95 \\
\hline $\mathrm{C}$ & 102 & 104 & 109 & 106 & 103 & 103 & 98 & 97 & 104 \\
\hline $\mathrm{D}$ & - & - & - & 102 & 98 & 100 & - & - & 99 \\
\hline $\mathrm{E}$ & - & - & - & 98 & 95 & 98 & - & - & 92 \\
\hline $\mathrm{F}$ & - & - & - & 73 & 95 & 101 & - & - & 100 \\
\hline $\mathrm{G}$ & - & - & - & 92 & 103 & 98 & - & - & 102 \\
\hline $\mathrm{H}$ & - & - & - & 80 & 107 & 98 & - & - & 98 \\
\hline
\end{tabular}

Only efficiency estimates for Labs A and B were used as the reference standard for the Phelps assay (Table 5). The efficiency estimates for the Phelps assay were somewhat similar for the Makah and ME03 isolates across laboratories (D-H) with 2 exceptions (Lab D for Makah isolate and Lab $\mathrm{H}$ for the ME03 isolate). Efficiency estimates were lower than the reference standard estimates for isolates 2004-175 and FPL2006-005 across laboratories.

\section{Repeatability and reproducibility}

The within-plate standard deviation, the betweenplate standard deviation, and the total standard deviation for each laboratory were estimated as described earlier using the Jonstrup and the Phelps assays (Table 6). There are no estimates provided for Lab $\mathrm{C}$ using the Phelps assay.

First, the standard deviation estimates (within plate, between plates, and total) were compared for Labs A to D where the differences observed are between labs/technicians and not the platform/software. The largest portion of observed variability for both assays is within-plate variability. Lab D $(0.14$, $0.04,0.15$ ) performed more consistently (smaller variance estimates) than Labs A $(1.34,<0.01,1.34)$, B $(0.49,0.07,0.49)$, or $C(0.89,0.02,0.89)$ using the Jonstrup assay. Similar analyses were completed for Labs E, F, G, and H, where differences observed are due to both differences in lab/technician and differences in the platform/software used. Lab $\mathrm{H}(0.88$, $0.01,0.88)$ performed similar to Lab C. Labs E $(0.39$, $0.10,0.39), F_{1}(0.33,0.05,0.34)$, and $G(0.29,0.04$, $0.29)$ performed most similar to Lab B. 


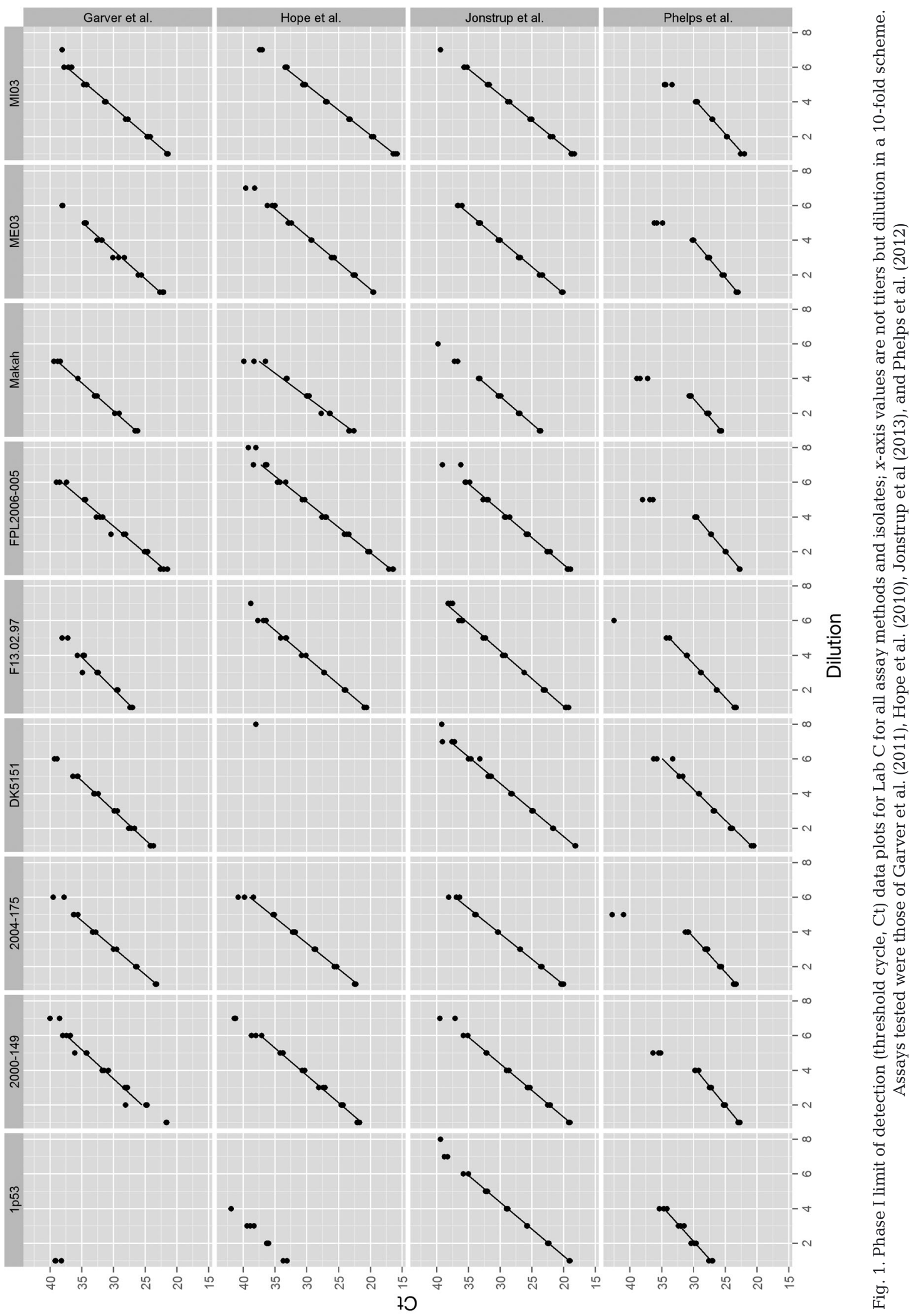




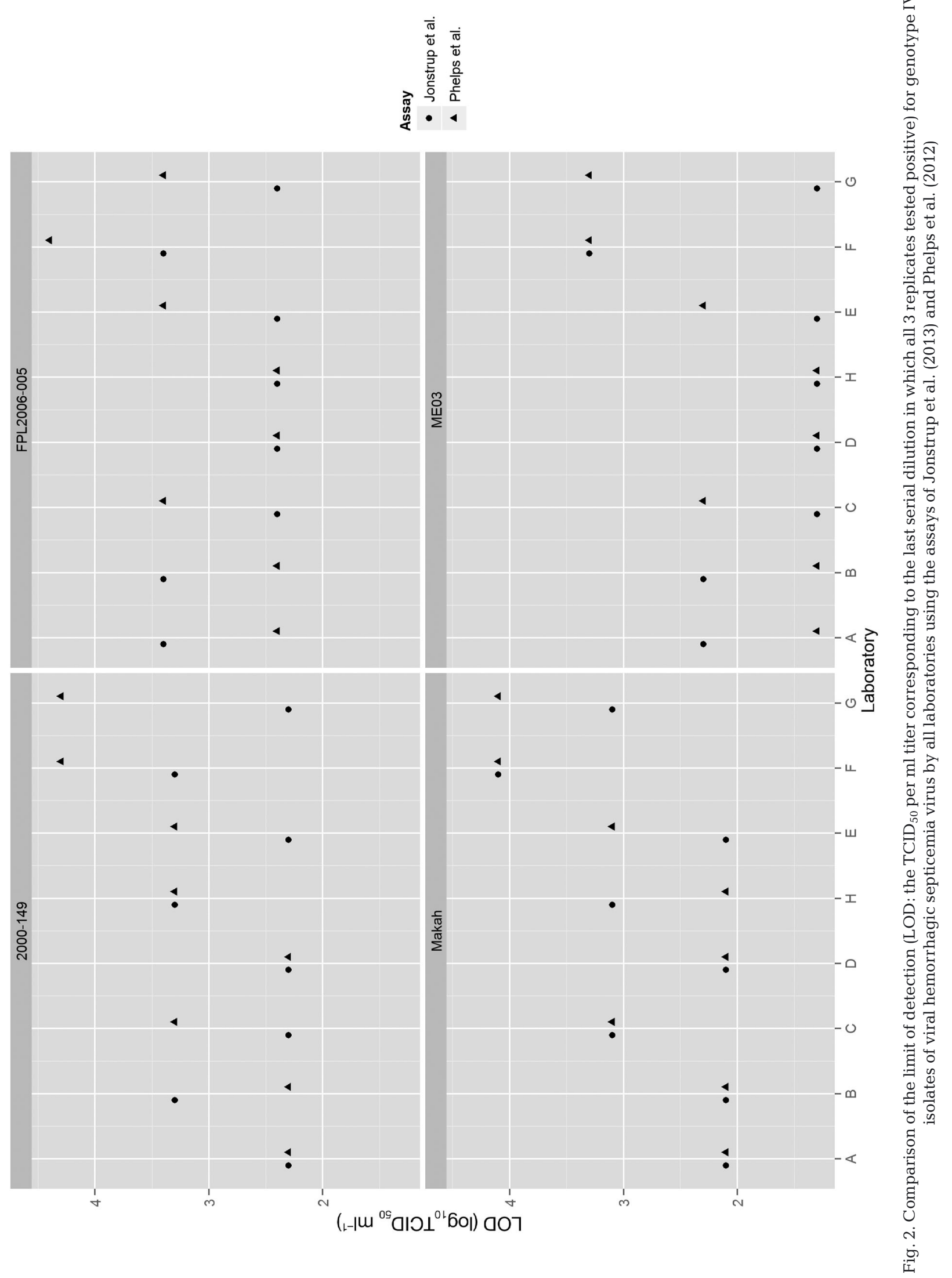


Table 6. Comparison of assay variation. Within-plate variability $=$ square root of the variance of the random error. Between-plate variability $=$ square root of the sum of the variances of the random plate and random dilution $\times$ plate effects. Total variability $=$ square root of the sum of all variance components

\begin{tabular}{|lcccc|}
\hline \multirow{2}{*}{$\begin{array}{l}\text { Method } \\
\text { Lab }\end{array}$} & $\begin{array}{l}\text { No. of } \\
\text { plates }\end{array}$ & \multicolumn{4}{l}{ Within plate } & Between plate & Total SD \\
\cline { 5 - 5 } Phelps et al. (2012) & & & \\
$\mathrm{A}$ & 5 & 1.01 & 0.76 & 1.27 \\
$\mathrm{~B}$ & 5 & 0.57 & 0.56 & 0.8 \\
$\mathrm{D}$ & 7 & 0.43 & 0.11 & 0.44 \\
$\mathrm{E}$ & 8 & 0.38 & 0.03 & 0.39 \\
$\mathrm{~F}_{1}$ & 2 & 0.79 & 1.17 & 1.41 \\
$\mathrm{~F}_{2}$ & 6 & 0.46 & 0.08 & 0.47 \\
$\mathrm{G}$ & 9 & 0.75 & 0.06 & 0.75 \\
$\mathrm{H}$ & 6 & 0.26 & 0.16 & 0.31 \\
Jonstrup et al. (2013) & & & \\
$\mathrm{A}$ & 5 & 1.34 & $<0.01$ & 1.34 \\
$\mathrm{~B}$ & 5 & 0.49 & 0.07 & 0.49 \\
$\mathrm{C}$ & 5 & 0.89 & 0.02 & 0.89 \\
$\mathrm{D}$ & 7 & 0.14 & 0.04 & 0.15 \\
$\mathrm{E}$ & 8 & 0.39 & 0.1 & 0.39 \\
$\mathrm{~F}_{1}$ & 5 & 0.33 & 0.05 & 0.34 \\
$\mathrm{~F}_{2}$ & 3 & 0.16 & 0.09 & 0.19 \\
$\mathrm{G}$ & 9 & 0.29 & 0.04 & 0.29 \\
$\mathrm{H}$ & 6 & 0.88 & 0.01 & 0.88 \\
\hline
\end{tabular}

Table 7. Efficiency estimates for the viral hemorrhagic septicemia virus (VHSV) MI03 RNA standards provided to the laboratories. The MI03 column shows regression analysis estimates obtained on serial dilutions made in the respective laboratory on the same virus stock as used by the coordinating laboratory to generate the VHSV MI03 RNA standards (positive amplification control). (-) virus not tested

\begin{tabular}{|c|c|c|c|c|c|c|c|c|c|c|}
\hline \multirow{2}{*}{$\begin{array}{l}\text { Method } \\
\text { Lab }\end{array}$} & & & & & \multirow{2}{*}{$\begin{array}{l}\text { Plate } \\
4\end{array}$} & \multirow[b]{2}{*}{5} & \multirow[b]{2}{*}{6} & \multirow[b]{2}{*}{7} & \multirow[b]{2}{*}{8} & \multirow[b]{2}{*}{9} \\
\hline & MI03 & 1 & 2 & 3 & & & & & & \\
\hline \multicolumn{11}{|c|}{ Phelps et al. (2012) } \\
\hline A & 110 & 149 & 133 & 123 & 133 & 129 & - & - & - & - \\
\hline B & 111 & 118 & 119 & 124 & 114 & 117 & - & - & - & - \\
\hline $\mathrm{C}^{\mathrm{a}}$ & 157 & - & - & - & - & - & - & - & - & - \\
\hline D & & 105 & 102 & 104 & 102 & 103 & 108 & 104 & - & - \\
\hline E & & 125 & 120 & 111 & 128 & 117 & 126 & 143 & 119 & - \\
\hline $\mathrm{F}_{1}$ & & 88 & 119 & - & - & - & - & - & - & - \\
\hline $\mathrm{F}_{2}$ & & 120 & 119 & 126 & 127 & 126 & 124 & - & - & - \\
\hline G & & 130 & 132 & 151 & 136 & 108 & 143 & 117 & 131 & 137 \\
\hline $\mathrm{H}$ & & 112 & 117 & 127 & 132 & 125 & 144 & - & - & - \\
\hline \multicolumn{11}{|c|}{ Jonstrup et al. (2013) } \\
\hline A & 97 & 96 & 96 & 98 & 97 & 101 & - & - & - & - \\
\hline B & 92 & 99 & 96 & 99 & 96 & 94 & - & - & - & - \\
\hline $\mathrm{C}$ & 98 & 94 & 103 & 99 & 98 & 95 & - & - & - & - \\
\hline D & & 98 & 97 & 98 & 98 & 98 & 96 & 99 & - & - \\
\hline E & & 98 & 97 & 102 & 97 & 98 & 96 & 100 & 98 & - \\
\hline $\mathrm{F}_{1}$ & & 104 & 109 & 102 & 99 & 109 & - & - & - & - \\
\hline $\mathrm{F}_{2}$ & & 98 & 99 & 99 & - & - & - & - & - & - \\
\hline $\mathrm{G}$ & & 99 & 102 & 104 & 100 & 108 & 99 & 102 & 105 & 100 \\
\hline $\mathrm{H}$ & & 100 & 98 & 100 & 97 & 99 & 98 & - & - & - \\
\hline
\end{tabular}

Lab D $(0.43,0.11,0.44)$ performed more consistently than Labs A $(1.01,0.76,1.27)$ and B $(0.57,0.56$, $0.80)$ on the Phelps assay. Estimates for total variability using the Phelps assay for Labs $\mathrm{E}(0.38,0.03,0.39)$, $\mathrm{F}_{2}(0.46,0.08,0.47)$, and $\mathrm{H}(0.26,0.16,0.31)$ were most similar to Lab B. However, there was a single plate tested by Lab $\mathrm{H}$ using both the Jonstrup and the Phelps assays in which the lowest concentration of the RNA standard did not produce a $\mathrm{Ct}$ value and had to be excluded in the variability estimates. This should be taken into consideration when assessing overall performance of this laboratory.

Estimates from regression analysis on the data from each laboratory for $\mathrm{Ct}$ values observed for the standardized positive amplification RNA controls supplied to laboratories (made from VHSV MI03) using the Jonstrup and the Phelps assays (Table 7) were compared. Estimates of efficiency were closer to $100 \%$ for the Jonstrup assay, while all estimates of efficiency for the Phelps assay were $>100 \%$. In general, the estimates of efficiency for all laboratories using the Jonstrup assay were similar. However, comparing the spread in values of the efficiency estimates, Labs A (96-101), B (92-99), D (96-99), E (96-102), and H (97-100) demonstrated a more consistent performance than Labs $\mathrm{C}$ (94103), $F_{1}$ (99-109), and $G$ (99-108) on the Jonstrup assay. Efficiency estimates using the Phelps assay were not as consistent within a lab or between labs. Lab D (102-108) and Lab B (111-124) performed similarly in terms of spread in values. Lab A (110149) efficiency estimates had a wider spread in the values than Labs D and B. Labs E, F, G, and H efficiency estimates were more variable and had larger spreads.

\section{Analytical specificity}

Genomic RNA from a wide variety of fish and fish pathogens that might be in a surveillance or diagnostic sample were evaluated for cross reactivity (exclusivity) with the primers and probes utilized in either the Jonstrup or the Phelps assay (Table 3). Lab G had 2 instances where Ct values were observed with the Phelps assay. A Ct value of 36.9 was observed for 1 of the 2 replicates of the 
high concentration of channel catfish virus (CCV), while both replicates of the low concentration had no observable Ct value. In addition, a Ct value of 31.5 was observed for 1 of the 2 replicates of the low concentration of fathead minnow nidovirus (FHMNV), while both replicates of the high concentration had no Ct values observed. All other pathogens and RNA extracted from fish tissues had no reportable Ct values with either the Jonstrup or the Phelps assays.

\section{DISCUSSION}

When making any comparison, some assumptions have to be made, and this was true in our study. First, we assumed that all operators were able to pipette appropriate volumes and were able to make a dilution sequence on a stock of virus. We also assumed (based on previous testing by the coordinating laboratory) that all stocks of viruses ( $>6$ logs) and the PAC set (standardized RNA samples over a 3-log template range) provided to the laboratories were homogenous and that the viral RNA in each vial was not impacted by storage or transport. However, we recognize that differences in laboratory/operator sensitivities may vary among labs (Jonstrup et al. 2013), and hence the selection of a robust assay that meets the testing purpose is paramount for deployment in a laboratory testing network.

Experience with conducting high-throughput testing volumes and maintaining strict quality assurance programs may have contributed to some labs having more consistent performance characteristics as demonstrated in this study (Table 2). Labs A, D, and E are large diagnostic labs and routinely test high volumes of samples by real-time PCR methods for multiple pathogens. In these labs, technicians with a high level of experience conducted the testing. Labs B and $\mathrm{H}$ are high-volume diagnostic labs in which the technicians routinely perform conventional PCR assays and were recently trained to perform real-time assays. Labs $\mathrm{C}$ and $\mathrm{G}$ have dual roles as both diagnostic and research labs with some experience with high throughput testing. Lab $\mathrm{F}$ is also involved in both research and diagnostics; here, the technicians were recently trained to perform real-time assays. Experience levels did not appear to impact the consistency of performance (AE estimates for the different VHSV genotype IV representatives or the RNA standard) when using the Jonstrup assay, and this consistency reflects on the robustness of the assay.

Data from 3 labs $(C, F$, and $G$ ) suggest that the Phelps assay may not be as robust and may be sensi- tive to variation in technical precision. Specifically, the linear regression analysis of the data set for several isolates and the PAC RNA set tested with the Phelps assay in Lab C did not hold a constant linear relationship between the $\mathrm{Ct}$ value and the concentration tested. As the same RNA for each isolate or same lot of PAC was utilized in all 4 assays, the failed linear relationships could have resulted from a technical issue during set up of the reactions. Sensitivity to technical precision is also evident in the data set for Lab F, where the assay was conducted by 2 different, less experienced operators in the same laboratory $\left(F_{1}\right.$ and $F_{2}$ ). Lab $G$ had 2 instances that most likely were false positive test results when testing $\mathrm{CCV}$ and FHMNV. A comparison of primer and probe sequences used in the Phelps assay with CCV strain Auburn 1, complete genome (GenBank NC_001493), and with the full genome sequence of 6 different isolates of FHMNV (GU002364 and Warg submissions pending) did not reveal a binding site that would generate an amplicon. It is most likely that the false positive results were due to contamination during either the extraction or during set up of the rRT-PCR.

In summary, 8 labs worked collectively to evaluate 4 standardized protocols according to the analytical criteria used to validate an assay as outlined in the OIE guidelines. Three labs established benchmark performance characteristics on a single platform/ software for all 4 assays on representative isolates from the 4 genotypes of VHSV. Plots of the regression analysis (data for Labs A and B not shown, Fig. 1 for Lab C) as it relates to the cut-off values utilized in all 4 assays suggest that cutoff values exceeded the linear relationship between the $\mathrm{Ct}$ value and $-\log _{10}$ dilution of the virus stock. Cut-off values were established in the original publications and may have been established to offset the fact that in samples where very low copy numbers of template are expected, the distribution of the template within the fish or sample varies, which would be the case in areas where disease is not known to occur. Additional testing would be necessary to determine the number of replicates required for each sample with the current cut-off values. An additional 5 laboratories were used to establish benchmark performance characteristics for the Jonstrup and the Phelps assays with platform and software changes.

In comparing benchmark performance characteristics (analytical sensitivity data) in order to select an assay for surveillance or regulatory purposes, a number of characteristics are used. Most importantly, the assay must detect all strains if the purpose is to declare freedom from a pathogen or to prevent intro- 
duction of a pathogen. Second, serial dilutions of reference isolates and inclusion of an RNA standard set provide limit of detection, dynamic range of the assay, and amplification efficiency estimates, all of which help predict the performance of the assay on diagnostic samples within a testing laboratory. Given the precious and limited amount of well characterized diagnostic samples available, it is ideal to determine these characteristics on isolates first.

Analytical performance measures were used collectively to formulate recommendations on the suitability of each of these assays for surveillance and diagnostic purposes pending further evaluation of each assay's diagnostic performance for its intended purpose. Clearly the Hope assay is not suitable for surveillance or diagnostic purposes when attempting to detect all genotypes, as it is not likely that this assay will detect VHSV genotypes I and II and was not considered further. However, this assay has clearly demonstrated to be a useful tool for surveillance of VHSV IVb in the Great Lakes (Bain et al. 2010, Cornwell et al. 2011, 2012). Phase I data established that while the Garver assay had efficiency estimates closer to $100 \%$ than the Phelps assay, the Phelps assay performed better in detecting all genotype representatives. The 2-step approach utilized in the Garver assay is generally more suited for diagnostic purposes on a limited number of samples or when sample size is an issue. One-step assays do provide an advantage when surveying large numbers of fish, as they are technically easier to perform, have fewer manipulations, and turnaround time is reduced. The Jonstrup and the Phelps assays are both 1-step assays and would be better suited for large-scale targeted surveillance efforts when testing is conducted in labs with high quality management and work practice systems and were chosen for further study (Warg et al. 2014, this volume).

The data in this study clearly demonstrate that the Jonstrup assay is the most robust of all 4 assays compared. This assay has a broader range of detection than the Phelps assay, and analytical performance characteristics across all platforms, software, and laboratories would predict the ability to detect weak positives better, and hence be more sensitive by this measure.

Acknowledgements. We thank Kyle Garver of Fisheries \& Oceans Canada, Pacific Biological Station, and Søren Jonstrup of the Section for Fish Diseases, National Veterinary Institute (Denmark), for sharing their testing protocols prior to publication; Elizabeth Brown and Julie Nelson of the Animal Disease Research and Diagnostic Laboratory, South Dakota State University; Gavin Glenney of the Lamar Fish
Health Center, US Fish and Wildlife Service; Mary Lea Killian of the Diagnostic Virology Laboratory, National Veterinary Services Laboratories; and Gael Kurath of the USGS Western Fisheries Research Center for helpful discussions. This work was funded by the USDA. Any use of trade, firm, or product names is for descriptive purposes only and does not imply endorsement by the US Government.

\section{LITERATURE CITED}

AFS-FHS (American Fisheries Society-Fish Health Section) (2010) Fish Health Section Blue Book: suggested procedures for the detection and identification of certain finfish and shellfish pathogens, 2010 edn. American Fisheries Society-Fish Health Section, Bethesda, MD

Bain MB, Cornwell ER, Hope KM, Eckerlin GE and others (2010) Distribution of an invasive aquatic pathogen (viral hemorrhagic septicemia virus) in the Great Lakes and its relationship to shipping. PLoS ONE 5:e10156

Chico V, Gomez N, Estepa A, Perez L (2006) Rapid detection and quantitation of viral hemorrhagic septicemia virus in experimentally challenged rainbow trout by real-time RT-PCR. J Virol Methods 132:154-159

> Cornwell ER, Eckerlin GE, Getchell RG, Groocock GH and others (2011) Detection of viral hemorrhagic septicemia virus by quantitative reverse transcription polymerase chain reaction from two fish species at two sites in Lake Superior. J Aquat Anim Health 23:207-217

> Cornwell ER, Eckerlin GE, Thompson TM, Batts WN and others (2012) Predictive factors and viral genetic diversity for viral hemorrhagic septicemia virus infection in Lake Ontario and the St. Lawrence River. J Gt Lakes Res 38:278-288

Cutrín JM, Olveira JG, Bandín I, Dopazo CP (2009) Validation of real time RT-PCR applied to cell culture for diagnosis of any known genotype of viral haemorrhagic septicaemia virus. J Virol Methods 162:155-162

Elsayed E, Faisal M, Thomas M, Whelan G, Batts W, Winton $\mathrm{J}$ (2006) Isolation of viral haemorrhagic septicaemia virus from muskellunge, Esox masquinongy (Mitchill), in Lake St Clair, Michigan, USA reveals a new sublineage of the North American genotype. J Fish Dis 29:611-619

Faisal M, Shavalier M, Kim RK, Millard EV and others (2012) Spread of the emerging viral hemorrhagic septicemia virus strain, genotype IVb, in Michigan, USA. Viruses 4: 734-760

Finney DJ (1978) Statistical methods in biological assays, 3rd edn. Griffin, London

> Gagné N, Mackinnon AM, Boston L, Souter B, Cook-Versloot M, Griffiths S, Olivier G (2007) Isolation of viral haemorrhagic septicaemia virus from mummichog, stickleback, striped bass and brown trout in eastern Canada. J Fish Dis 30:213-223

> Garver KA, Hawley LM, McClure CA, Schroeder T and others (2011) Development and validation of a reverse transcription quantitative PCR for universal detection of viral hemorrhagic septicemia virus. Dis Aquat Org 95: 97-112

> Groocock GH, Getchell RG, Wooster GA, Britt KL and others (2007) Detection of viral hemorrhagic septicemia in round gobies in New York State (USA) waters of Lake Ontario and the St. Lawrence River. Dis Aquat Org 76: 187-192

Groocock GH, Frattini SA, Cornwell ER, Coffee LL, Wooster 
GA, Getchell RG, Bowser PR (2012) Experimental infection of four aquacultured species with viral hemorrhagic septicemia virus Type IVb. J World Aquacult Soc 43: 459-476

Hershberger PK, Gregg JL, Grady CA, Taylor L, Winton JR (2010) Chronic and persistent viral hemorrhagic septicemia virus infections in Pacific herring. Dis Aquat Org 93:43-49

Hope KM, Casey RN, Groocock GH, Getchell RG, Bowser PR, Casey JW (2010) Comparison of quantitative RT-PCR with cell culture to detect viral hemorrhagic septicemia virus (VHSV) IVb infections in the Great Lakes. J Aquat Anim Health 22:50-61

Jonstrup SP, Kahns S, Skall HF, Boutrup TS, Olesen NJ (2013) Development and validation of a novel Taqmanbased real-time RT-PCR assay suitable for demonstrating freedom from viral haemorrhagic septicaemia virus. J Fish Dis 36:9-23

Kim R, Faisal M (2010a) Comparative susceptibility of representative Great Lakes fish species to the North American viral hemorrhagic septicemia virus Sublineage IVb. Dis Aquat Org 91:23-34

Kim RK, Faisal M (2010b) The Laurentian Great Lakes strain (MI03) of the viral haemorrhagic septicaemia virus is highly pathogenic for juvenile muskellunge, Esox masquinongy (Mitchill). J Fish Dis 33:513-527

Kim R, Faisal M (2010c) Experimental studies confirm the wide host range of the Great Lakes viral haemorrhagic septicaemia virus genotype IVb. J Fish Dis 33:83-88

Kim RK, Faisal M (2012) Shedding of viral hemorrhagic septicemia virus (Genotype IVb) by experimentally infected muskellunge (Esox masquinongy). J Microbiol 50: 278-284

Liu Z, Teng Y, Liu H, Jiang Y and others (2008) Simultaneous detection of three fish rhabdoviruses using multiplex real-time quantitative RT-PCR assay. J Virol Methods 149:103-109

Lumsden JS, Morrison B, Yason C, Russell S and others (2007) Mortality event in freshwater drum Aplodinotus grunniens from Lake Ontario, Canada, associated with viral haemorrhagic septicemia virus, Type IV. Dis Aquat Org 76:99-111

Matejusova I, McKay P, McBeath AJA, Collet B, Snow M (2008) Development of a sensitive and controlled realtime RT-PCR assay for viral haemorrhagic septicaemia

Editorial responsibility: Mark Crane, Geelong, Victoria, Australia virus (VHSV) in marine salmonid aquaculture. Dis Aquat Org 80:137-144

Matejusova I, McKay P, Bland F, Snow M (2010) Application of a sensitive, specific and controlled real-time PCR assay to surveillance indicates a low prevalence of viral haemorrhagic septicaemia virus (VHSV) in wild herring, Clupea harengus L., in Scottish waters. J Fish Dis 33: 841-847

OIE (World Organization for Animal Health) (2012) Manual of diagnostic tests for aquatic animals. OIE, Paris

Phelps NB, Patnayak DP, Jiang Y, Goyal SM (2012) The use of a one-step real-time reverse transcription polymerase chain reaction (rRT-PCR) for the surveillance of viral hemorrhagic septicemia virus (VHSV) in Minnesota. J Aquat Anim Health 24:238-243

Pierce LR, Willey JC, Crawford EL, Palsule VV and others (2013a) A new StaRT-PCR approach to detect and quantify fish viral hemorrhagic septicemia virus (VHSv): enhanced quality control with internal standards. J Virol Methods 189:129-142

Pierce LR, Willey JC, Palsule VV, Yeo J, Shepherd BS, Crawford EL, Stepien CA (2013b) Accurate detection and quantification of the fish viral hemorrhagic septicemia virus (VHSv) with a two-color fluorometric realtime PCR assay. PLoS ONE 8:e71851

Shah R, Luo E, Fung CL (2009) A high-throughput workflow for the extraction of aquaculture pathogen DNA/RNA from aquatic tissues. American Association of Veterinary Laboratory Diagnosticians, 52nd Annual Conference, San Diego, CA, p 146

Smail DA, Snow M (2011) Viral haemorrhagic septicaemia. In: Woo PTK, Bruno DW (eds) Fish diseases and disorders, Book 3. CAB International, Wallingford, p 110-142

Tordo N, Benmansour A, Calisher C, Dietzgen RG and others (2005) Family Rhabdoviridae. In: Fauquet CM (ed) Virus taxonomy. Eighth Report of the International Committee on Taxonomy of Viruses. Elsevier Academic Press, San Diego, CA, p 623-644

Vardeman SB, Jobe JM (1999) Statistical quality assurance methods for engineers. John Wiley \& Sons, New York, NY

Warg JV, Clement T, Cornwell ER, Cruz A and others (2014) Detection and surveillance of viral hemorrhagic septicemia virus using real-time RT-PCR. II. Diagnostic evaluation of two protocols. Dis Aquat Org 111:000-000

Submitted: July 22, 2013; Accepted: April 16, 2014 Proofs received from author(s): July 31, 2014 